University of Nebraska - Lincoln

DigitalCommons@University of Nebraska - Lincoln

GEOGRAPHIC VARIATION IN SONG OF THE BRIGHT-RUMPED ATTILA (TYRANNIDAE: ATTILA SPADICEUS): IMPLICATIONS FOR SPECIES STATUS

\author{
Daniel Leger \\ University of Nebraska-Lincoln, dleger1@unl.edu \\ D. James Mountjoy \\ Knox College
}

Follow this and additional works at: https://digitalcommons.unl.edu/psychfacpub

Part of the Psychiatry and Psychology Commons

Leger, Daniel and Mountjoy, D. James, "GEOGRAPHIC VARIATION IN SONG OF THE BRIGHT-RUMPED ATTILA (TYRANNIDAE: ATTILA SPADICEUS): IMPLICATIONS FOR SPECIES STATUS" (2003). Faculty Publications, Department of Psychology. 477.

https://digitalcommons.unl.edu/psychfacpub/477

This Article is brought to you for free and open access by the Psychology, Department of at DigitalCommons@University of Nebraska - Lincoln. It has been accepted for inclusion in Faculty Publications, Department of Psychology by an authorized administrator of DigitalCommons@University of Nebraska - Lincoln. 


\title{
GEOGRAPHIC VARIATION IN SONG OF THE BRIGHT-RUMPED ATTILA (TYRANNIDAE: ATTILA SPADICEUS): IMPLICATIONS FOR SPECIES STATUS
}

\author{
Daniel W. Leger ${ }^{1,3}$ and D. James Mountjoy ${ }^{2}$ \\ ${ }^{1}$ Nebraska Behavioral Biology Group and Department of Psychology, University of Nebraska, Lincoln, \\ Nebraska 68588-0308, USA; and \\ ${ }^{2}$ Department of Biology, Knox College, Galesburg, Illinois 61401, USA
}

\begin{abstract}
AвSTRACT.-Bright-rumped Attilas (Attila spadiceus) have two song forms, one sung primarily at dawn, the other primarily during the rest of the day. Both songs consist of a main phrase and an optional terminal phrase. Our recordings of dawn and day songs in Costa Rica were very similar to those made elsewhere in Central America. However, Central American dawn songs were significantly different than dawn songs from South America, both in terms of quantitative features (temporal and frequency variables) and qualitative characteristics (note shape). Day songs from Central and South America were similar. Song differences suggest that the Bright-rumped Attila may be two species, one in Central America, the other in South America. Received 25 January 2002, accepted 25 August 2002.
\end{abstract}

\begin{abstract}
Resumen.-Attila spadiceus tiene dos tipos de canto, uno emitido principalmente al amanecer y otro emitido durante el resto del día. Ambos cantos consisten de una frase principal y una frase terminal opcional. Nuestras grabaciones de cantos del amanecer y el día fueron muy similares a otros hechos en otros lugares de Centro América. Sin embargo, los cantos del amanecer centroamericanos fueron significativamente diferentes de los suramericanos, en términos de caracteres tanto cuantitativos (variables de tiempo y frecuencia) como cualitativos (forma de las notas). Los cantos del día de Centro y Sur América fueron similares. Las diferencias en el canto sugieren que A. spadiceus podría comprender dos especies, una centroamericana y una suramericana.
\end{abstract}

SONG FEATURES HAVE been instrumental in our understanding of the evolution and biogeography of suboscine birds. Several pairs of tyrant flycatcher species have been recognized based, at least in part, on vocal differences. Examples include Couch's (Tyrannus couchii) and Tropical (T. melancholicus) kingbirds (Traylor 1979a), Pacific-slope (Empidonax difficilis) and Cordilleran (E. occidentalis) flycatchers (Johnson 1980), Caribbean pewees (Contopus spp.; Reynard et al. 1993), Suiriri flycatchers (Zimmer et al. 2001), and Inezia tyrannulets (Zimmer and Whittaker 2000b). Isler et al. (1998) have advocated the use of vocalizations for use in avian systematics and their approach is gaining favor in the identification of cryptic species among antbirds (Whitney et al. 2000, Zimmer and Whittaker 2000a).

Twelve subspecies of the Bright-rumped Attila (Attila spadiceus) have been recognized

\footnotetext{
${ }^{3}$ E-mail: dleger1@unl.edu
}

(Traylor 1979b), and those appear to segregate into three allopatric groups. The northern group, which comprises 10 of the subspecies, ranges from southern Mexico through Panama and into northwestern South America. The second group consists of the nominate subspecies, spadiceus, which has a widespread distribution from Venezuela through Amazonia. The third group occurs only in a narrow strip of Brazilian Atlantic rainforest and consists of the subspecies uropygiatus.

Skutch (1971) described the life history of attilas in Costa Rica, but little else has been published on the genus. Both Skutch (1971) and Farabaugh (1982) mentioned that both sexes sing, and Skutch (1971) indicated that individual birds sing both of the two song forms that he described.

In this article, we describe the dawn and day songs of Bright-rumped Attilas in Costa Rica and compare them with recordings made elsewhere in Central and South America. 


\section{Methods}

Our recordings were made at the La Selva Biological Station $\left(10^{\circ} 26^{\prime} \mathrm{N}, 8^{\circ} 59^{\prime} \mathrm{W}\right)$ in northeastern Costa Rica during March 1998 and March 2000, and at the Las Cruces Biological Station $\left(8^{\circ} 47^{\prime} \mathrm{N}, 82^{\circ} 57^{\prime} \mathrm{W}\right)$ in southern Costa Rica in March 2002. The recordings were made with Sony TCM5000EV, Sony TCD-D8, and Tascam DA-P1 recorders equipped with Sennheiser ME67 and MKH70 microphones. They will be deposited at the Borror Laboratory of Bioacoustics, Ohio State University. Our recordings (20 of dawn song and 24 of day song) included 796 songs from 28 individuals (estimated by locations of the singing birds). In the analyses that follow, we represent this corpus of recordings by mean values of dawn songs and day songs separately for La Selva and Las Cruces. In addition, we analyzed 29 recordings obtained from sound archives, individual recordists, and published recordings. Those sources are described in the Appendix. In total, we analyzed 352 songs from those sources.

Recordings were digitized (22 kHz, 16-bit) using CANARY 1.2.4 software (Cornell Laboratory of Ornithology, Ithaca, New York) on Macintosh computers. Sonograms were used to measure duration of the main phrase of the song and its lowest and highest frequencies. We also counted the number of syllables (dawn songs) or notes (day songs) in the main phrase, and measured the following intersong interval. The presence or absence of terminal phrase elements was also noted. Recordings varied in number of songs present, so we computed the mean for each variable for each recording and used those data for analyses of geographic variation.

\section{Results}

Bright-rumped Attilas sing two distinct song forms. Dawn songs in Costa Rica are much more common before 0600 and after 1700 , but occur sparingly during the intervening hours. The opposite is true of day songs. Both dawn and day songs vary in number and type of notes and syllables and in the presence or absence of a terminal phrase. Most of the variability we observed at La Selva and Las Cruces could be observed within a recording of an individual bird (D. W. Leger unpubl. data).

Dawn song consists of a main phrase and a terminal phrase. The main phrase has three syllable types that differ primarily in number of notes. The two-note syllable was by far the most common. The terminal phrase, which was often omitted, consisted of either one note ("whew") or two ("whew-whit"). All the recordings from southern Mexico through western Panama were very similar to songs that we recorded in Costa Rica (Figure 1).
Dawn songs from Central America differed significantly from those in South America (Figure 2). The Central American dawn song main phrases were significantly longer but had only marginally more syllables per song, probably because Central American birds included more three-noted syllables. Central American main phrases were significantly higher on both frequency measures (Table 1).

In addition to the quantitative variables, dawn song note structure was clearly different. In Central America, dawn song notes are linear upsweeps; in South America, however, they are inverted "U"s. Further, although birds in both regions commonly append a terminal phrase to the main phrase of the song, only 4 of the 15 South American recordings had the "whit" note that was frequently present in the Central American recordings. Finally, in Central America, the "whit" note covered a broad fre-

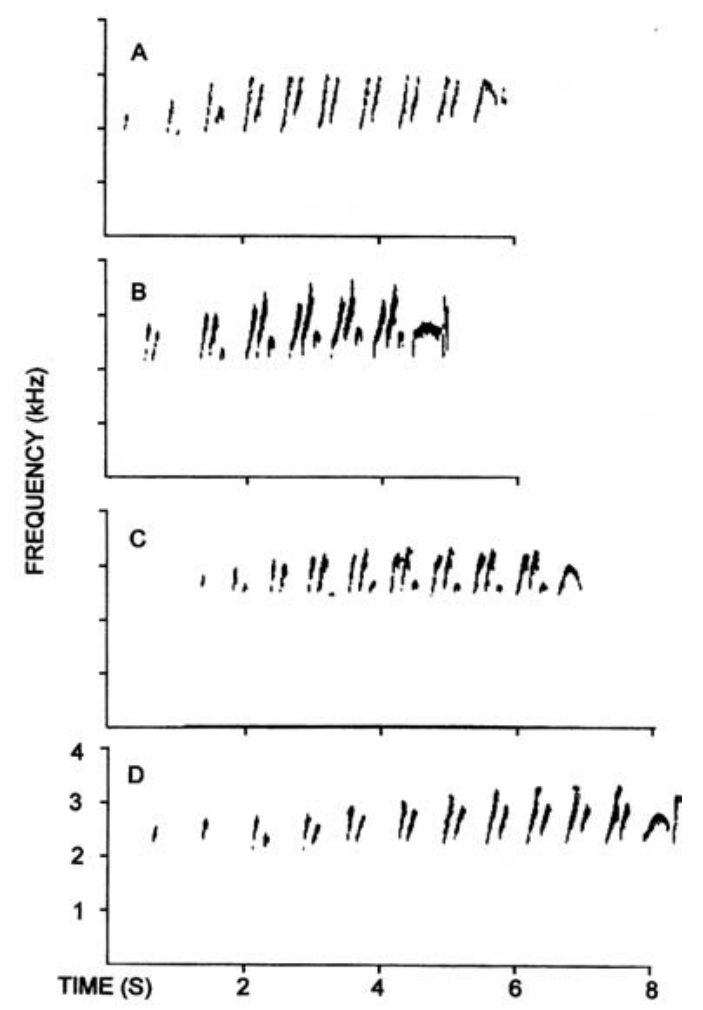

Fig. 1. Examples of dawn songs recorded in Central America. (A) Mexico, FMNH 691; (B) Nicaragua, FMNH 1360; (C) and (D) La Selva, Costa Rica, by the authors. (A), (B), and (D) end with "whew-whit"; (C) ends with "whew" only. See Appendix for recording information. 

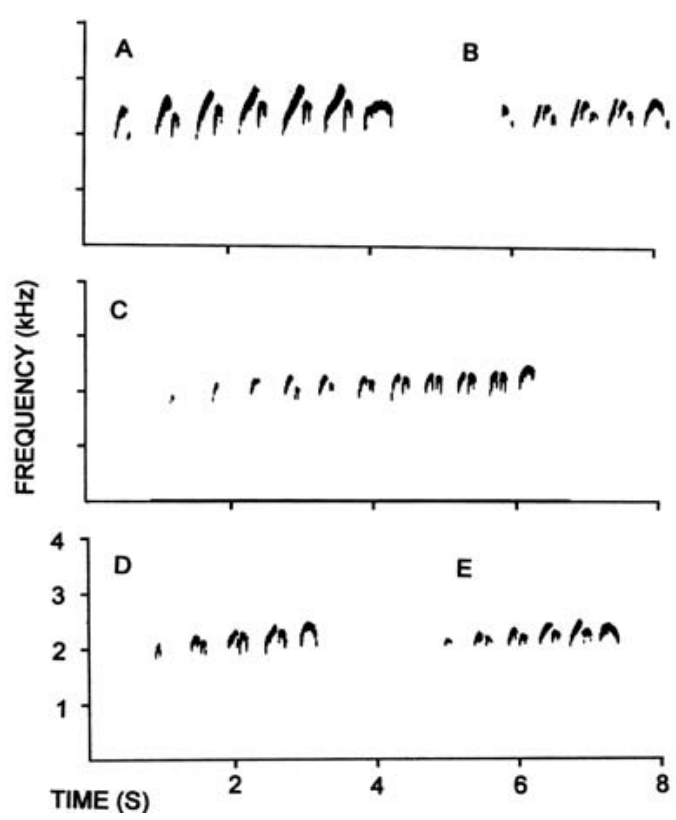

FIG. 2. Examples of dawn songs recorded in South America. (A) Colombia, NSA 27351; (B) Venezuela, LNS 49324; (C) Ecuador, J. V. Moore (unpubl. data); (D) Brazil, LNS 48651; (E) Brazil, J. Minns, 10 November 1997. (B) ends in "whew-whit"; all others end in "whew" only. See Appendix for recording information.

quency range whereas in South America the "whit" note was greatly reduced in range.

Two recordings of dawn songs had features that were intermediate to those that were typical of the Central American and South American forms. One recording was made near Cali, Colombia, and the other at an unspecified loca-

TABLE 1. Summary of dawn song characters recorded in Central America (CA, $n=16$ recordings) and South America (SA, $n=15$ recordings).

\begin{tabular}{lccc}
\hline & $\begin{array}{c}\text { CA } \\
\text { mean }\end{array}$ & $\begin{array}{c}\text { SA } \\
\text { mean }\end{array}$ & $F^{\mathrm{a}}$ \\
\hline $\begin{array}{l}\text { Number of } \\
\text { syllables }\end{array}$ & 7.12 & 5.65 & 4.89 \\
$\begin{array}{l}\text { Lowest } \\
\text { frequency (kHz) }\end{array}$ & 2.04 & 1.84 & $14.63^{*}$ \\
$\begin{array}{l}\text { Highest } \\
\text { frequency } \\
\begin{array}{l}\text { Main phrase } \\
\text { duration (s) }\end{array}\end{array}$ & 3.17 & 2.59 & $55.90^{*}$ \\
$\begin{array}{l}\text { Intersong } \\
\text { interval (s) }\end{array}$ & 4.17 & 2.80 & $13.46^{*}$ \\
$\begin{array}{l}\text { Songs with } \\
\text { terminal phrase }\end{array}$ & 3.49 & 3.74 & 0.11 \\
$\begin{array}{l}\text { adf }=1 \text { and } 29 \text { for all variables except intersong interval (df }=1 \text { and } 23) . \\
{ }^{*} P<0.05 \text { after applying Bonferroni procedure. }\end{array}$ &
\end{tabular}

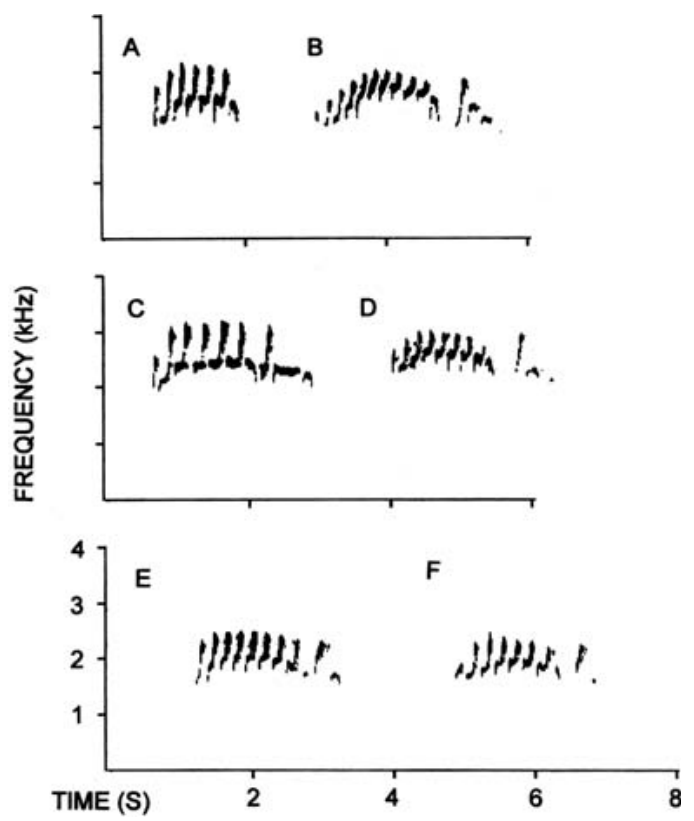

Fig. 3. Examples of day songs recorded in Central and South America. (A) and (B) La Selva, Costa Rica, and (C) Las Cruces, Costa Rica, by the authors; (D) Panama, FMNH 1188; (E) Ecuador, J. V. Moore (unpubl. data); (F) Peru, Schulenberg et al. (2000). All but (A) have the terminal phrase. See Appendix for recording information.

tion in Panama. Both had a linear upswept first note like that of the Central American birds, but an inverted-U shaped second note, typical of the South American birds. The Colombian song is shown in Figure 2.

Day songs also have a main phrase and an optional terminal phrase. The main phrase's

TABLE 2. Summary of day song characters recorded in Central America (CA, $n=10$ recordings) and South America (SA, $n=5$ recordings). None of the pairs of means differed significantly (all $P>0.05)$.

\begin{tabular}{lccc}
\hline Variable & $\begin{array}{c}\text { CA } \\
\text { mean }\end{array}$ & $\begin{array}{c}\text { SA } \\
\text { mean }\end{array}$ & $F^{\mathrm{a}}$ \\
\hline $\begin{array}{l}\text { Number of } \\
\text { syllables }\end{array}$ & 7.40 & 6.74 & 0.53 \\
$\begin{array}{l}\text { Lowest } \\
\text { frequency (kHz) }\end{array}$ & 1.95 & 1.82 & 0.71 \\
$\begin{array}{l}\text { Highest } \\
\text { frequency } \\
\begin{array}{l}\text { Main phrase } \\
\text { duration (s) }\end{array}\end{array}$ & 3.18 & 2.77 & 4.24 \\
$\begin{array}{l}\text { Intersong } \\
\text { interval (s) }\end{array}$ & 1.39 & 1.14 & 1.45 \\
$\begin{array}{l}\text { Songs with } \\
\text { terminal phrase }\end{array}$ & 5.95 & 2.69 & 1.55 \\
\hline adf $=1$ and 13 for all variables except intersong interval (df $=1$ and 10$).$
\end{tabular}


primary note type is roughly J-shaped, but the first and last notes are often different. The most common terminal phrase is a series of three notes that tend to drop successively in frequency. Although day songs were variable (Fig. 3), we found no evidence of systematic regional differences in those songs, either on quantitative variables (Table 2) or on qualitative features such as note shape. That conclusion is tentative, however, because only five recordings of day song from South America were available.

\section{DisCUSSION}

Geographic variation in song among suboscine birds has been taken to indicate genetic divergence. Coopmans and Krabbe (2000) have expressed an opinion that seems to be widely shared among Neotropical ornithologists: "...the growing knowledge of bird sounds in the Neotropics will shed further light on the taxonomy of the Tyrannidae, and... will lead to the discovery of additional species" (p. 305). The discovery of crypic species on the basis of differences in acoustic signal structure is occurring in other taxa as well, including insects and mammals (Henry 1994, Jones 1997).

Isler et al. (1998) have suggested that the number of significantly different acoustic features can be used as a metric for assigning specific or subspecific status to geographically defined populations. By their criteria, the Central American and South American Bright-rumped Attilas would qualify as distinct species. Attilas from Central America differ from those in South America in several characters of their dawn song, are larger in several morphological measurements (D. W. Leger unpubl. data), and do not seem to exhibit plumage polymorphism to the same degree as the South American birds (Ridgely and Tudor 1994). If recognized as a distinct species, the Central American attilas would be referred to as Attila flammulatus Lafresnaye, 1848 , because that appears to be the earliest name applied to any of the subspecies in the group. Flammulated Attila would be an appropriate English name for this species.

Our analyses indicate that Bright-rumped Attilas have markedly different dawn songs in Central and South America. Much smaller differences were noted in the day songs from the two regions. That pattern of variation follows one observed in wood-warblers, in which there are regional differences in dawn song, but little geographic variation in day song (Kroodsma 1981). Those regional dialects in oscines are often considered evidence for song learning. We are not claiming that attilas learn their song features, but merely want to keep open the possibility that song-learning may occur in some suboscines. To date, the only report of suspected song learning in suboscine passerines is that of Snow (1977) who, on the basis of analyses of Three-wattled Bellbirds (Procnias tricarunculata) in Costa Rica, concluded that those birds improvise and imitate songs. The pattern of geographic variation in dawn and day songs of attilas is consistent with a pattern known to exist in oscines, in which song-learning may be universal, although additional work will be needed to determine whether song-learning occurs in attilas or in other suboscines.

\section{ACKNOWLEDGMENTS}

We thank the Organization for Tropical Studies for the opportunity to work at La Selva and Las Cruces, and to their staffs for their hospitality. We thank Macauley Laboratory of Natural Sounds, Borror Laboratory of Bioacoustics, Florida Museum of Natural History, and National Sound Archive of the British Library for providing recordings. A. Priori, S. Gaunt, T. Webber, and K. Williams of these institutions were especially helpful. J. Minns supplied us with recordings from Brazil, and J. V. Moore kindly gave us additional information about his published recordings. We extend our appreciation to all the recordists who made their work available. We thank D. Willard of the Field Museum for facilitating access to their collections. The Nebraska Behavioral Biology Group, Franklin and Marshall College, and Knox College provided funding for this work. A. De Pierre and D. Lackaff assisted with sonagraphic analyses, and C. Arenz, D. Nelson, and two anonymous reviewers contributed helpful suggestions on an earlier version of the manuscript.

\section{Literature Cited}

Coopmans, P., and N. Krabbe. 2000. A new species of flycatcher (Tyrannidae: Myiopagis) from eastern Ecuador and eastern Peru. Wilson Bulletin 112:305-312.

English, P. H., AND T. A. PARKer III. 1992. Birds of Eastern Ecuador. Cornell Laboratory of Ornithology, Ithaca, New York.

Farabaugh, S. M. 1982. The ecological and social significance of duetting. Pages 85-124 in Acoustic Communication in Birds, vol. 2: Song Learn- 
ing and its Consequences (D. E. Kroodsma and E. H. Miller, Eds.). Academic Press, New York.

Henry, C. S. 1994. Singing and cryptic speciation in insects. Trends in Ecology and Evolution 9: 388-392.

Isler, M. L., P. R. Isler, AND B. M. Whitney. 1998. Use of vocalizations to establish species limits in antbirds (Passeriformes: Thamnophilidae). Auk 115:577-590.

JoHNSON, N. K. 1980. Character variation and evolution of sibling species in the Empidonax difficilis-flavescens complex (Aves:Tyrannidae). University of California Publications in Zoology 112:1-151.

JONES, G. 1997. Acoustic signals and speciation: The roles of natural and sexual selection in the evolution of cryptic species. Advances in the Study of Behavior 26:317-354.

Kroodsma, D. E. 1981. Geographical variation and functions of song types in warblers (Parulidae). Auk 98:743-751.

Reynard, G. B., O. H. Garrido, and R. L. Sutton. 1993. Taxonomic revision of the Greater Antillean Pewee. Wilson Bulletin 105:217-227.

Ridgely, R. S., And G. Tudor. 1994. The Birds of South America, vol. II: The Suboscine Passerines. University of Texas Press, Austin.

Ross, D. L., AND B. M. Whitney. 1995. Voices of Costa Rican Birds: Caribbean Slope. Library of Natural Sounds, Ithaca, New York.

Schulenberg, T. S., C. A. Marantz, and P. H. EnGLISH. 2000. Voices of Amazonian Birds. Birds of the Rainforest of Southern Peru and Northern Bolivia, vol. 3: Ground Antbirds (Formicariidae) through Jays (Corvidae). Cornell Laboratory of Ornithology, Ithaca, New York.

SкUTCH, A. F. 1971. Life history of the Bright-rumped Attila Attila spadiceus. Ibis 113:316-322.

SNOw, B. 1977. Territorial behavior and courtship of the male Three-wattled Bellbird. Auk 94: 623-645.

Traylor, M. A., JR. 1979a. Two sibling species of Tyrannus (Tyrannidae). Auk 96:221-233.

TRayLOR, M. A., JR., ED. 1979b. Check-list of Birds of the World. Museum of Comparative Zoology, Cambridge, Massachusetts.

Whitney, B. M., J. F. Pacheco, D. R. C. Buzzetti, AND R. PARRINI. 2000. Systematic revision and biogeography of the Herpsilochmus pileatus complex, with description of a new species from northeastern Brazil. Auk 117:869-891.

Zimmer, K. J., AND A. WhitTAKer. 2000a. The Rufous Cacholote (Furnariidae: Pseudoseisura) is two species. Condor 102:409-422.

Zimmer, K. J., And A. Whittaker. 2000b. Species limits in Pale-tipped Tyrannulets (Inezia: Tyrannidae). Wilson Bulletin 112:51-66.

Zimmer, K. J., A. Whittaker, and D. C. Oren. 2001. A cryptic new species of flycatcher (Tyrannidae: Suiriri) from the cerrado region of central South America. Auk 118:56-78.

Associate Editor: D. A. Nelson
APPENDIX. Recordings used in analyses of geographic variation in song. Acronyms for recording archives: $\mathrm{BLB}=$ Borror Laboratory of Bioacoustics, Ohio State University; NSA = National Sound Archives, British Library; LNS = Macauley Library of Natural Sounds, Cornell University; FMNH = Florida Museum of Natural History, University of Florida.

\section{Central America}

Belize: Cayo District (D. Archibald McCallum, 24 December 1991, BLB 20500); Gallon Jug (John V. Moore, 1992 in J. V. Moore unpubl. data); Columbia River Forest Reserve (John Gilardi, no date, in J. Gilardi unpubl. data).

Costa Rica: Puerto Limon (Luis F. Baptista, 14 February 1992, BLB 18221); Puntarenas (R. Grimshaw, 31 January 1982, LNS 27245); Parque Nacional Corcovado (David L. Ross, Jr., 28 January 1989, in Ross and Whitney 1995); Monteverde Cloud Forest Reserve (David L. Ross, Jr., 11 March 1990, in Ross and Whitney 1995); La Selva and Las
Cruces Biological Stations (Daniel W. Leger and D. James Mountjoy, this study); La Selva Biological Station (J. W. Hardy, 14 July 1981, FMNH 603); Monteverde (B. Snow, 5 June 1974, NSA 11457); Talamanca (T. C. White, 26 April 1984, NSA 12964); La Selva Biological Station (Ranft, 28 February 1985, NSA 15856 and NSA 15857).

Guatemala: Tikal (H. McGuinness, 25 May 1991, FMNH 1324).

Mexico: Jalisco (A. Sada, 14 February 1987, FMNH 899); Veracruz (J. A. Cox, 8 April 1985, FMNH 691)

Nicaragua: Zelaya Department (T. Will, 7 March 1990, FMNH 1360 species cuts 33 and 34).

Panama: unspecified location (A. B. van den Berg, 29 March 1981, LNS 28423); Cerro Jefe (Theodore A. Parker III, 3 Feb 1982, LNS 25650); Isla Mahe (P. Polchek, 19 February 1989, FMNH 1188).

SOUTH AMERICA

Brazil: Amazonas (Mario Cohn-Haft, 8 November 1989, LNS 48651); Espirito Santo (J. Minns, 10 
November 1997 and 29 October 1998); Bahia (J. Minns, 3 May 1999, 30 April 1999).

Colombia: Cali (D. Willis, 16 August 1989, NSA 27351). Ecuador: Napo (John V. Moore, no date, in J. V. Moore unpubl. data).

Peru: Madre de Dios (Theodore A. Parker III, 22 October 1981, LNS 24257; 2 September 1982, LNS 29814); Madre de Dios (Arnoud B. van den Berg, no date, in English and Parker 1992); Madre de Dios (P.
K. Donahue, no date, NSA 34539); Madre de Dios (C. A. Marantz, no date, in Schulenberg et al. 2000). Suriname: Raleigh Falls (P. Trail, 5 August 1979, LNS 21017); unspecified location (V. Mees-Balchin, 31 July 1972, NSA 08997).

TRINIDAD: Arima Valley (T. C. White, 27 February 1974, NSA 06433).

Venezuela: Bolivar (C. D. Duncan, 17 August 1989, LNS 49324). 